VOL. 2 NO. 2 (2019) : 83-87

\title{
PROFIL REPRESENTASI MATEMATIS SISWA DALAM MENYELESAIKAN MASALAH MATEMATIKA DENGAN MEDIA SCREENCAST O MATIC
}

\author{
Sri Devi Wulandari \\ Universitas Nusantara PGRI Kediri, srideviwulandari321@gmail.com \\ Received : 25 Mei 2019, Revised : 5 Oktober 2019, Accepted : 6 Oktober 2019 \\ (C) Mathematics Education Unugiri 2019
}

\begin{abstract}
The purpose of this study is to describe the profile of mathematical representation of students who are capable of early mathematics while resolving mathematical problems in three-dimensional material with O Matic screencast media. The research approach that will be used by researchers is qualitative. The type of research that used in this study is descriptive qualitative research, namely by analyzing existing data to obtain information about the profiles of mathematical representations to solve problems in the material of the Three dimensions with the O Matic screencast media. The research phase is the introduction, planning, research, and completion stage. This study uses test questions, interviews, and observation sheets. The results of this study subject able to meet the three indicators of mathematical representation ability that have been determined, but the final results of the answers are still less precise because they misunderstand the problem of the problem.
\end{abstract}

Keywords: representation, three-dimensional, screencast-o-matic

\begin{abstract}
Abstrak
Tujuan penelitian ini adalah untuk mendeskripsikan profil representasi matematis siswa yang berkemampuan awal matematika sedang dalam menyelesaikan masalah matematika pada materi dimensi tiga dengan media screencast o matic. Pendekatan penelitian yang digunakan oleh peneliti adalah pendekatan penelitian kualitatif. Jenis penelitian yang digunakan dalam penelitian ini adalah penelitian kualitatif deskriptif, yaitu dengan cara menganalisis data yang ada untuk memperoleh informasi mengenai profil representasi matematis siwa untuk memecahkan soal pada materi dimensi Tiga dengan media screencast o matic. Tahap penelitian yaitu pendahuluan, perencanaan, pelaksanaan penelitian dan tahap penyelesaian. Penelitian ini menggunakan instrumen soal tes, wawancara dan lembar observasi. Hasil penelitian ini adalah subjek mampu memenuhi ketiga indikator kemampuan representasi matematis yang telah ditentukan, namun hasil akhir jawabannya masih kurang tepat karena salah memahami permasalahan soal.
\end{abstract}

Kata kunci: representasi, dimensi tiga, screencast-o-matic

\section{Pendahuluan}

Kemampuan representasi merupakan suatu kemampuan matematika dengan pengungkapan ide-ide matematika (masalah, pernyataan, definisi, dan lain-lain) dalam berbagai cara [7]. Hal ini sejalan dengan pendapat [1] menambahkan bahwa representasi merupakan dasar atau fondasi bagaimana seorang siswa dapat memahami dan menggunakan ide-ide matematika. representasi berperan dalam proses penyelesaian masalah dalam matematika. Hal ini sejalan dengan pendapat [2] bahwa Kemampuan representasi matematis adalah kemampuan yang dimiliki dalam menyajikan kembali gambar, tabel, grafik, simbol, notasi, diagram, persamaan atau ekspresi matematis serta kata-kata/teks tertulis dalam bentuk yang lain.

Kemampuan representasi matematis membantu siswa dalam membangun konsep, 
memahami konsep, dan menyatakan ide-ide matematis, serta memudahkan untuk mengembangkan kemampuan yang dimilikinya. Namun pada kenyataannya, kemampuan representasi matematis masih menjadi hal yang sulit bagi siswa. Hal ini sesuai dengan pendapat [3] bahwa siswa cenderung meniru langkah guru dalam menyelesaikan masalah. Akibatnya, kemampuan representasi matematis siswa menjadi tidak berkembang.

Untuk itu, suatu proses pembelajaran harus dibuat semenarik mungkin agar siswa antusias dalam belajar yaitu dengan membuat media pembelajaran yang memudahkan siswa dalam memahami konsep.

NCTM [8] menjelaskan teknologi penting dalam belajar dan mengajar matematika, teknologi mempengaruhi matematika yang diajarkan dan meningkatkan proses belajar siswa. Seperti halnya screencast $o$ matic yang penggunaannya merupakan aktivitas windows dan rekaman suara yang juga dapat mengganti pengalaman langsung dalam pembelajaran [4] dengan begitu siswa dapat belajar secara mandiri dan dapat memutar secara berulang-ulang materi yang diajarkan oleh guru sehingga siswa akan lebih memahami konsep yang diajarkan.

Berdasarkan studi pendahuluan yang dilakukan peneliti, kebanyakan siswa memiliki persepsi bahwa matematika merupakan pelajaran yang sangat sulit dan membosankan bahkan ada yang tidak tahu kegunaan matematika dalam kehidupan sehari-hari. Kemudian saat peneliti bertanya kepada siswa, siswa menyatakan bahwa masih kesulitan dalam mengerjakan soal aplikasi turunan, siswa kesulitan dalam mengubah kalimat matematika menjadi gambar, model matematika, bahkan siswa belum bisa menuliskan apa yang diketahui dan ditanyakan dari soal tersebut. Hal tersebut membuktikan bahwa kemampuan representasi matematis siswa masih rendah.

Berdasarkan uraian di atas maka peneliti tertarik untuk meneliti tentang "Profil Representasi Matematis Siswa dalam Menyelesaikan Masalah Matematika Dengan Media Screencast O Matic". Agar suatu penelitian dapat terlaksana dengan baik dan sesuai sasaran, maka suatu penelitian harus memiliki tujuan. Tujuan dari penelitian ini adalah sebagai berikut :

1. Mendeskripsikan kemampuan representasi visual siswa setelah ditunjang dengan media screencast o matic.

2. Mendeskripsikan kemampuan representasi simbol siswa setelah ditunjang dengan media screencast o matic.

Mendeskripsikan kemampuan representasi verbal siswa setelah ditunjang dengan media screencast o matic.

\section{Pembahasan}

Proses belajar mengajar seringkali dihadapkan pada materi yang abstrak dan diluar pengalaman siswa sehari-hari, sehingga materi ini menjadi sulit dipahami siswa seperti hal nya matematika. Visualisai termasuk salah satu cara yang dapat dilakukan untuk mengkonkritkan sesuatu yang abstrak. Gambar dua dimensi atau model tiga dimensi yang sering digunakan dalam proses belajar mengajar. Pada era informatika visualisasi berkembang dalam bentuk gambar bergerak (animasi) yang dapat ditambahkan suara (audio). Menurut [5] pengetahuan tentang media pembelajaran sangat berguna untuk menyusun perencanaan program pengajaran.

Pendekatan penelitian yang digunakan oleh peneliti adalah pendekatan penelitian kualitatif. Jenis penelitian yang digunakan dalam penelitian ini adalah penelitian kualitatif deskriptif, yaitu dengan cara menganalisis data yang ada untuk memperoleh informasi mengenai profil representasi matematis siwa untuk memecahkan soal pada materi dimensi Tiga dengan media screencast o matic. Informasi atau data tersebut dapat diperoleh dari hasil tes dan wawancara subjek penelitian.

Indikator yang digunakan dalam penelitian ini yaitu:

1. Representasi visual meliputi:

Siswa dapat mengubah soal dalam bentuk gambar

2. Representasi simbol meliputi: 
a. Siswa dapat mengubah masalah kedalam model matematika

b. Siswa dapat menyelesaiakan model matematika untuk menentukan jawaban

3. Representasi verbal meliputi:

Siswa dapat menjawab dengan teks tertulis

Tahapan penelitian dalam penelitian yang dilakukan adalah sebagai berikut :

1. Tahap Pendahuluan

2. Tahap Perencanaan

3. Tahap Pelaksanaan Penelitian

4. Tahap Penyelesaian

Tempat yang digunakan dalam penelitian adalah jenjang SMA sederajat kelas XII. Subjek yang digunakan dalam penelitian adalah siswa SMA kelas XII yang dipilih berdasarkan kemampuan awal matematika dan pertimbagan guru. Mekanisme dalam menentukan subjek adalah sebagai berikut yang terlihat pada Gambar 1.

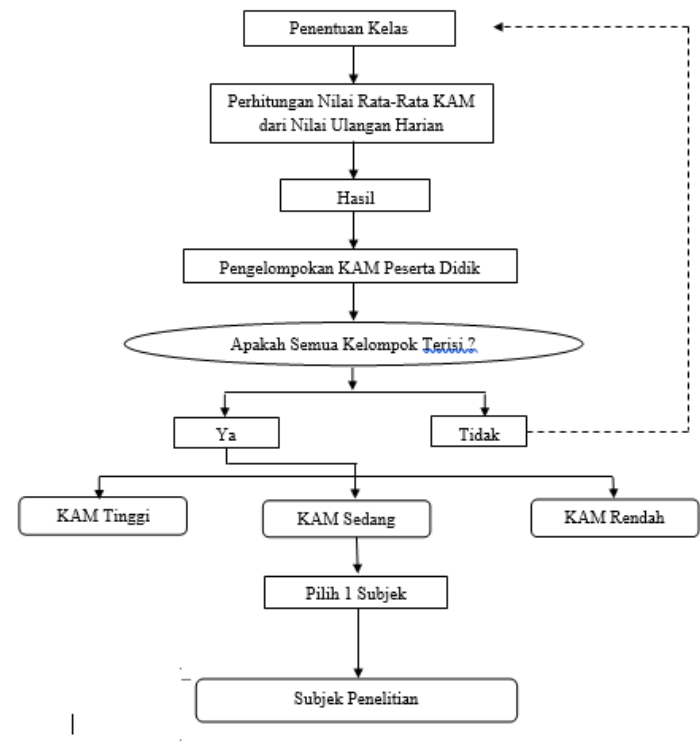

Gambar 1. Mekanisme Penentuan Subjek

Dalam penelitian ini ada 2 jenis instumen yaitu instrument utama dan instrument bantu. Instrumen utama adalah peneliti itu sendiri, sesuai dengan pendapat [6] yang menyatakan bahwa dalam penelitian kualitatif, yang menjadi instrumen atau alat penelitian adalah peneliti itu sendiri. Oleh karena itu peneliti sebagai instrumen harus divalidasi seberapa jauh peneliti kualitatif siap melakukan penelitian yang selanjutnya terjun ke lapangan dan instrumen bantu yang berupa media screencast o matic, soal tes, wawancara dan dokumentasi.

Teknik Analisis Data

1. Data Reduction (Reduksi data)

2. Data Display (Penyajian data)

3. Conclusion Drawing ( Penarikan Kesimpulan)

Pengecekan Keabsahan Temuan

1. Uji Credibility

2. Pengujian Dependability (Reliabilitas)

3. Pengujian Confirmability (Objektivitas)

Tahap penelitian kualitatif dalam deskripsi hasil penelitian ini akan disajikan menjadi beberapa bagian, diantaranya mulai dari penentuan subjek dari masing-masing kategori, analisis data, dan hasil penelitian tentang profil representasi matematis siswa dalam menyelesaikan masalah matematika dengan screencast o matic pada materi dimensi tiga. Presentase subjek dapat dilihat pada tabel 1 :

Tabel 1. Persentase Subjek Penelitian

\begin{tabular}{lcc}
\hline $\begin{array}{c}\text { Kemampuan } \\
\text { awal } \\
\text { matematika }\end{array}$ & $\begin{array}{c}\text { Banyak } \\
\text { siswa }\end{array}$ & $\begin{array}{c}\text { Persentase } \\
(\%)\end{array}$ \\
\hline Tinggi & 7 & 28 \\
Sedang & 13 & 52 \\
Rendah & 5 & 20 \\
\hline
\end{tabular}

Berdasarkan tabel 1 diperoleh siswa dengan kemampuan awal matematika tinggi sebesar $28 \%$, siswa dengan kemampuan awal matematika sedang sebesar $52 \%$, dan siswa dengan kemampuan awal rendah sebesar $20 \%$. Peneliti memilih siswa dengan perolehan presentase terbesar dengan jumlah 1 subjek dan atas pertimbangan guru, siswa yang dipilih adalah siswa yang komunikatif.

Triangulasi yang digunakan adalah triangulasi teknik.

a. Tujuan

Untuk menguji kredibilitas data yang diperoleh dan hasil penelitian yang lebih kredibel/ dapat dipercaya.

b. Proses

Dalam proses triangulasi teknik dilakukan dengan cara mengecek data 
kepada sumber yang sama dengan teknik yang berbeda, teknik yang digunakan dalam penelitian ini yaitu tes tulis, wawancara, observasi, dan dokumentasi.

Untuk memperjelas triangulasi teknik dengan menggunakan metode tes dan wawancara, maka dapat dilihat dari hasil rincian masing-masing indikator sebagai berikut.

Tabel 2. Triangulasi Teknik

\begin{tabular}{|c|c|c|c|}
\hline Indikator & Wawancara & Tes & $\begin{array}{c}\text { Vali } \\
\text { ditas }\end{array}$ \\
\hline $\begin{array}{l}\text { Representasi } \\
\text { visual } \\
\text { meliputi: } \\
\text { a.Siswa } \\
\text { dapat } \\
\text { mengubah } \\
\text { soal dalam } \\
\text { bentuk } \\
\text { gambar }\end{array}$ & $\begin{array}{l}\text { 1.Subjek bisa } \\
\text { menjadikan } \\
\text { dalam bentuk } \\
\text { gambar }\end{array}$ & $\begin{array}{l}\text { Subjek } \\
\text { mampu } \\
\text { mengubah } \\
\text { dalam } \\
\text { bentuk } \\
\text { gambar. }\end{array}$ & Valid \\
\hline $\begin{array}{l}\text { Representasi } \\
\text { simbol } \\
\text { meliputi: } \\
\text { a.Siswa dapat } \\
\text { mengubah } \\
\text { masalah dalam } \\
\text { model } \\
\text { matematika. } \\
\text { b.Siswa dapat } \\
\text { menyelesaikan } \\
\text { model } \\
\text { matematika } \\
\text { untuk } \\
\text { menentukan } \\
\text { jawaban }\end{array}$ & $\begin{array}{l}\text { 1.Subjek } \\
\text { dapat } \\
\text { mengubah } \\
\text { soal cerita } \\
\text { dalam } \\
\text { kalimat } \\
\text { matematika } \\
\text { 2.Subjek } \\
\text { dapat } \\
\text { menjelaskan } \\
\text { hasil } \\
\text { pekerjaannya } \\
\text { dari awal } \\
\text { hingga akhir }\end{array}$ & $\begin{array}{l}\text { Siswa } \\
\text { menuliskan } \\
\text { proses } \\
\text { dalam } \\
\text { menjawab } \\
\text { soal sampai } \\
\text { kettemu } \\
\text { hasil } \\
\text { akhirnya. }\end{array}$ & Valid \\
\hline $\begin{array}{l}\text { Representasi } \\
\text { verbal } \\
\text { meliputi: } \\
\text { a.Siswa dapat } \\
\text { menjawab } \\
\text { dengan teks } \\
\text { tertulis. }\end{array}$ & $\begin{array}{l}\text { 1.Subjek } \\
\text { kebingungan } \\
\text { dalam } \\
\text { menarik } \\
\text { kesimpulan }\end{array}$ & $\begin{array}{l}\text { Siswa tidak } \\
\text { menyimpul } \\
\text { kan hasil } \\
\text { pekerjaann } \\
\text { ya }\end{array}$ & Valid \\
\hline
\end{tabular}

Dalam penelitian ini yang dimaksud dengan profil merupakan gambaran mengenai keadaan seseorang yang dipandang dari segi kemampuan representasi matematis dalam menyelesaikan soal matematika pada materi Dimensi Tiga setelah diberikan materi dengan menggunakan media screencast o matic.

Berdasarkan uraian ringkasan, pembahasan dari subjek yang mewakili kemampuan awal matematika sedang dapat dilihat bahwa penelitian ini secara umum dari ketiga indikator, subjek dapat memenuhi tiga indikator yaitu Representasi visual meliputi: Siswa dapat mengubah soal dalam bentuk gambar; Representasi simbol meliputi: Siswa dapat mengubah masalah kedalam model matematika, Siswa dapat menyelesaiakan model matematika untuk menentukan jawaban; Representasi verbal meliputi: Siswa dapat menjawab dengan teks tertulis.

Pada indikator Representasi visual meliputi: Siswa dapat mengubah soal dalam bentuk gambar, subjek mampu merubah soal kedalam gambar persegi panjang beserta ukurannya. Subjek menggambarkan proses yang diinginkan soal dalam bentuk gambar.

Pada indikator Representasi simbol meliputi: Siswa dapat mengubah masalah kedalam model matematika, subjek mampu menuliskan simbol matematika dari soal yaitu volume, panjang, rumus kubus, dll. Kemudian untuk indikator Siswa dapat menyelesaiakan model matematika untuk menentukan jawaban, subjek sudah mampu menjawab soal berdasarkan prosesnya, Subjek melakukan operasi sudah benar dan subjek mampu menjelaskan jawabannya, walaupun jawaban akhir siswa masih belum tepat, karena salah dalam pemahaman mengenai bagian karton yang dipotong. Hal ini sesuai dengan teori yang disampaikan oleh Wardhani [9] yaitu terkait memberikan bukti atau alasan terhadap kebenaran solusi.

Pada indikator Representasi verbal meliputi: Siswa dapat menjawab dengan teks tertulis terlihat bawa siswa menuliskan apa yang ada dipikirannya kedalam lembar jawaban yang ada, siswa menuliskan prosesnya secara lengkap pada lembar jawaban.

\section{Penutup}

Berdasarkan hasil analisis dan pembahasan sebelumnya, peneliti membuat kesimpulan tentang profil representasi matematis siswa dengan media screencast o matic, yang mana media ini sangat membantu siswa dalam memvisualisasikan konsep 
matematika yang abstrak sehingga siswa akan lebih mudah memahami konsep matematika yang diberikan. Berdasarkan siswa berkemampuan awal matematika sedang dengan 4 siklus, yaitu memilih subjek penelitian, memberi materi dimensi tiga dengan media screencast o matic, memberi soal tes kepada subjek, dan mengklarifikasi subjek dengan wawancara. Secara umum ketiga indikator dapat dicapai subjek namun subjek masih salah pemehaman dengan soal tes sehingga membuat hasil akhir subjek masih kurang tepat.

Dengan adanya pembelajaran menggunakan media pembelajaran akan memudahkan siswa dalam memahami konsep, karena media pembelajaran bertujuan sebagai alat visualisai termasuk salah satu cara yang dapat dilakukan untuk mengkonkritkan sesuatu yang abstrak.

Berdasarkan hasil penelitian dan kesimpulan, peneliti mengemukakan saran sebagai berikut :

1. Bagi Peserta Didik

Melalui hasil penelitian ini dapat dijadikan sebagai acuan untuk memperluas dan mengasah tahapan-tahapan proses representasi dalam menyelesaikan soal matematika. Gunakan referensi lain seperti teknologi informasi (media pembelajaran) untuk menggali kemampuan representasi sehingga tidak pernah bosan dalam menerima konsep materi.

2. Bagi Guru

Hasil penelitian dapat digunakan guru sebagai informasi tentang profil representasi matematis siswa berkemampua sedang dalam menyelesaikan soal matematika yang nantinya dapat digunakan sebagai dasar untuk memilih dan memilah model pembelajaran yang tepat untuk siswa. Gunakan pembelajaranpembelajaran yang menarik yaitu dengan media pembelajaran sehingga dapat meningkatkan kemampuan representasi siswa. Buatlah media screencast o matic yang dapat digunakan siswa dalam belajar mandiri.

3. Bagi Peneliti Selanjutnya
Melalui hasil penelitian ini diharapkan dapat dijadikan referensi dalam melakukan penelitian selanjutnya dengan memperluas dan memperdalam ruang lingkup penelitian.

\section{Referensi}

[1] Dahlan, J. A., Materi Pokok Analisis Kurikulum Matematika. Jakarta: Universitas Terbuka, (2011)..

[2] Hartono, M. Firdaus, dan Supriyanti, Kemampuan Representasi Matematis dalam Materi Fungsi dengna Pendekatan Open Ended pada siswa kelas VIII MTs Sirajul Ulum Pontianak. Jurnal Eksponen, (2019) 9-20.

[3] Kartini, Peranan Representasi dalam Pembelajaran Matematika. Seminar Nasional Matematika dan Pendidikan Matematika, Yogyakarta, 5 Desember 2009. Diambil dari http://core.ac.uk, pada tanggal 19 Mei 2019.

[4] Kurniawan, D. dan S. V. Dewi, Pengembangan Perangkat Pembelajaran dengan Media Screencast-O-Matic Mata Kuliah Kalkulus 2 Menggunakan Model 4D Thiagarajan, Jurnal Siliwangi, (2017) 214-219.

[5] Sagala, S., "Konsep dan Makna Pembelajaran: Untuk Membantu memecahkan problematika belajar dan mengajar". Bandung: Alfabeta, (2013).

[6] Sugiyono, "Metode Penelitian Pendidikan Pendekatan Kuantitatif, kualitatif dan $R \& D ”$. Bandung: Alfabeta, (2016).

[7] Syafri, F. Kemampuan Representasi Matematis dan Kemampuan Pembuktian Matematika. Jurnal Edumath, (2017) 9-20.

[8] Van De Walle, J. A., "Pengembangan Pengajaran Matematika Sekolah Dasar dan Menengah", Edisi Keenam Jilid 1. Jakarta: Erlangga, (2008).

[9] Wardhani, S., dkk. "Pembelajaran kemampuan pemecahan masalah matematikadi SMP”. Yogyakarta : PPPPTK matematika, (2010). 